\title{
Reflexões sobre educação indígena na poética de Efraín Miranda
}

\author{
Ednéia Rodrigues Ribeiro ${ }^{1}$
}

\begin{abstract}
Resumo: Este trabalho pretende analisar os poemas "E Q" e "Ñ R", publicados em Indios dios runa: antologia poética del profeta del fuego (2008), do peruano Efraín Miranda. A partir da tensão entre pares - dentro/fora, professor/aluno, indígena/nãoindígena, rural/urbano - representados pelas imagens da "indiecita escolar", em "EQ", e das professoras, em "ÑR", serão apontadas semelhanças e diferenças entre esses poemas. Tal dicotomia será associada à maneira encontrada pelo poeta para criticar a implementação de políticas educacionais que, em vez de valorizar a sabedoria indígena, caracterizam-se pela tentativa de aculturação desses povos.
\end{abstract}

Palavras-chave: Literatura peruana. Efraín Miranda. Indio dios runa. Educação indígena.

\section{Reflections on indigenous education in the poetics of Efraín Miranda}

\begin{abstract}
This study aims at analyzing the poems "E Q" and "N R", published in Indios dios runa: antologia poética del profeta del fuego (2008), by Peruvian Efraín Miranda. From the tension between word pair - inside / outside, teacher / student, indigenous / non-indigenous, rural / urban - represented by the images of "school indigeta", in "EQ", and the teachers, in "NR", it will be pointed out similarities and differences between these poems. This dichotomy will be associated with the way in which the poet found to criticize the implementation of educational policies that, instead of valuing indigenous wisdom, are characterized by the attempt to acculturate these peoples.
\end{abstract}

Keywords: Peruvian Literature. Efraín Miranda. Indio dios runa. Indigenous education.

\section{Reflexiones sobre la educación indígena en la poética de Efraín Miranda}

Resumen: Este trabajo pretende analizar los poemas "E Q" y "Ñ R", publicados en Indios dios runa: antología poética del profeta del fuego (2008), del peruano Efraín Miranda. A partir de la tensión entre pares - dentro/fuera, profesor/alumno, indígena/ no indígena, rural/urbano - representados por imágenes de la indiecita escolar, en EQ, y de las profesoras, en NRR, serán apuntadas semejanzas y diferencias entre esos poemas. Tal dicotomía será asociada a la manera encontrada por el poeta para criticar la implementación de políticas educacionales que, en lugar de valorar la sabiduría

\footnotetext{
${ }^{1}$ Doutora em Letras-Estudos Literários. Professora de Literatura do Instituto Federal do Norte de Minas Gerais (IFNMG), campus Montes Claros. MG, Brasil. E-mail: edneiarr@yahoo.com.br. ORCID: https://orcid.org/0000-0002-7070-7912.
} 
indígena, se caracterizan por la tentativa de aculturación de estos pueblos.

Palabras clave: Literatura peruana. Efraín Miranda. Indio dios runa. Educación indígena.

\section{Apresentação}

"Soy un mestizo ambiguo, contracditorio: un indio aculturado o un blanco quechuizado. [...] alguien doblemente marginal." (Efraín Miranda).

Efraín Miranda Luján nasceu em Puno, em 1925, e faleceu em Arequipa, em abril de 2015. Entre 1948 e 1950, juntamente com Oswaldo Reynoso e Aníbal Portocarrero, integrou o grupo literário Abemur, vinculado-se à denominada Geração de 50. Estreou com o livro Muerte cercana (1954) publicado durante o período em que se muda para Lima à procura de emprego. Após frustrada tentativa de residir e trabalhar na capital peruana, retorna a Puno, onde se torna professor primário de escolas públicas, em meados de 1960. A formação autodidata revela seu envolvimento com o cânone literário universal, sendo visto como herdeiro de Stéphane Mallarme. Também, é considerado "un poeta indio" por muitos estudiosos de sua obra, como Gonzalo Espino Relucé e Mauro Mamani Macedo, por exemplo. Tal característica deve-se à marcante presença de temáticas indígenas, sobretudo a partir do segundo livro, Choza (1978), que rompe um silêncio de mais de 20 anos, desde a estreia do poeta com Muerte Cercana. Foi publicado após ter se estabelecido na comunidade de Jacha-Huinchoca, onde mora por cerca de 30 anos, para atuar como professor da Escola Fiscal № 893. A universalidade da poesia índia de Miranda contribui para a construção da memória e da identidade do Peru, motivo pelo qual ele figura como um dos mais relevantes poetas no cenário cultural desse país, no século XX. Apesar da qualidade poética e da relevância dos assuntos abordados, ainda pode ser visto como um poeta à margem do cânone. Portanto, precisa ser cada vez mais lido e divulgado, principalmente em outros países da América Latina.

$\mathrm{O}$ fato de ter vivido em comunidades indígenas por muitos anos modificou significativamente a poesia de Miranda, conforme ele mesmo admitira em entrevista a Christian Reynoso: "Todo ese contacto que tuve con los indios en la comunidad cambió por completo mi cultura y mi forma de percibir la vida y el universo... era otra 
sociedad, otra realidad y yo me fui adaptando a ella."2 A convivência com os moradores, o contato com a língua quéchua e a cosmovisão indígena levou o poeta a situá-los como protagonistas de sua obra. Por meio da criação poética buscou apresentar o ponto de vista dos povos andinos de Arequipa e Puno, em vez de reforçar a ótica centralista, canônica e excludente de Lima.

Ao inserir o indígena em sua poesia, Miranda torna-se peculiar, no contexto literário peruano, porque seus versos não se limitam à contemplação ou à descrição estereotipada. De modo radical, reivindica a identidade desses povos, denunciando a destruição do mundo andino ao mesmo tempo em que lança um chamado a defendê-lo. Segundo Relucé (2008, p. 06), o eu lírico dos poemas de Miranda é diferente dos demais porque indica a universalidade da sua poesia índia, na medida em que "se apropria de la letra para proponer una visión índia y su inevitable ubicación universal al tiempo de instalarse como contra-cultura".

O livro Indios dios runa: antologia poética del profeta del fuego (2008), organizado por Gonzalo Espino Relucé, contém uma seleção de poemas que abordam temas indígenas a partir de diversos ângulos. Dividida em sete partes - Cristales de hielo perpetuo; Iliclla; contorsionan mi lengua; Padre Sol, Madre Tierra; Empasto de barro e Rebaño de corvinas para pastar - essa coletânea apresenta textos que refletem sobre questões linguísticas, culturais e sociais, muitas vezes, contrapondo a visão andina a outras que usufruem de mais prestígio. Conta com 48 poemas publicados inicialmente em livros independentes de Miranda - Muerte Cercara (1954), Choza (1978), Vida (1980) e Padre Sol (1998). Nota-se certa peculiaridade desde os títulos dos poemas. Ou são ausentes, como nos quatro poemas extraídos do livro de 1954, ou são nomeados por duas letras, traço que se repete nas publicações de 1978 e 1980. Os textos do derradeiro livro, porém, trazem como título apenas dois algarismos arábicos.

Entre os poemas que integram a antologia Indios dios runa, este trabalho se dedicará à análise de "E Q" e "Ñ R"3, porque suscitam reflexões sobre a oferta de ensino público aos povos indígenas. A escolha por esse corpus deve-se ao fato de tais poemas, embora publicados em momentos diferentes, tratarem de um mesmo assunto a partir de perspectivas distintas. A análise comparativa de ambos possibilita ao leitor

\footnotetext{
${ }^{2}$ Disponível em http://punoculturaydesarrollo.blogspot.com/2015/04/efrain-miranda-in-memoriamcontinua.html

${ }^{3}$ Publicados pela primeira vez nos livros Choza (1978) e Vida (1980), respectivamente.
} 
visualizar questões relacionadas à educação indígena por mais de um ângulo, tanto pelo olhar do aluno-indígena quanto do professor-branco. A partir de uma ótica bifurcada, mesmo que em alguns pontos se entrecruze, será possível refletir sobre dilemas envolvendo a implementação de escolas em territórios indígenas, na maioria das vezes, sem o cuidado de estabelecer conexões com a realidade local.

O poema "E Q" costuma ser citado em estudos sobre a educação indígena, como, por exemplo, "Exclusión social y cultural: La educación em plobaciones indígenas como reto para la intervención professional", de Graciela Soldevilla Velazco e Delma Gonzales Ríos. Na condição de docentes de uma universidade ${ }^{4}$ localizada em território cuja metade da população é falante das línguas quéchua e aymara, as autoras refletem sobre a urgência de se incluir os povos indígenas de maneira integral. Questionam o histórico processo de exclusão que abrange aspectos sociais, econômicos, políticos e culturais, com ênfase à educação.

Ao traçar uma espécie de percurso da educação indígena no Peru - desde quando esteve atrelada à evangelização, na fase da colonização, até tentativas de implementação de políticas públicas, a partir das primeiras décadas do século XX - indica-se a aculturação acentuada por tais projetos. Mesmo iniciativas que visavam demonstrar a importância de a cultura ocidental incorporar a vida dos povos indígenas, e não o contrário, tornaram-se frágeis quando postas em prática. É o caso da proposta do Ministro da Educação, Luís E. Valcárcel membro de grupo indigenista Ressurgimento, em 1945.

Nessa fase, são implantados os Núcleos escolares campesinos, nos quais, além de ações educativas, seriam criados refeitórios e hortas em terrenos cedidos pelas comunidades, a fim de relacionar a aprendizagem na escola ao trabalho. Entretanto, como não foram elaborados materiais didáticos adequados, os ensinamentos continuaram a ser transmitidos em castelhano, com base em vivências do meio urbano. Nota-se, portanto, certo desencontro entre o projeto ideológico e sua execução, conforme indicam as autoras:

La educación indígena trató de incorporar a los grupos etnolingüisticos a una sociedad "semi-industrializada" reconociendo su derecho a la educación y a una capacitación manual para el trabajo. Los intentos por revalorar la cultura, la lengua y el desarrollo de sus

\footnotetext{
${ }^{4}$ Universidad Nacional del Altiplano Puno-Perú.
} 
potencialidades humanas fueron muy breves y no se incorporaron al sistema escolar. (VELAZCO; RÍOS, 2000, p. 16).

Alguns versos do poema "E Q", de Efraín Miranda, são citados para ilustrar o descompasso entre teoria e prática quando se trata de projetos de educação indígena. É importante salientar que Miranda atuou como professor em comunidades andinas, a partir da década de 1970, após a fase dos Núcleos escolares campesinos. Para além do contexto analisado por Velazco e Ríos, esse poema de Miranda pode ser lido como uma epígrafe quando se trata de conflitos culturais envolvendo a educação indígena, em diversos momentos, tanto no Peru quanto em demais países da América Latina.

A experiência do poeta em escolas rurais instaladas em territórios indígenas ocorre após a reforma educativa de 1972, que propunha: ensino bilíngue (respectiva língua indígena/castelhano); alfabetização de adultos, com base nas ideias de Paulo Freire; oferta de educação inicial para crianças indígenas; e apoio aos jovens egressos dos núcleos campesinos. Contudo, muitos desafios, principalmente relacionados à linguagem, continuaram a colocar em dúvida a efetividade de tais políticas, como indica um dos testemunhos atribuídos a professores que lecionaram nessas escolas:

El mayor problema con los niños indígenas es el miedo que le tienen a la escuela, [...] estos niños que solo hablan quechua, son muy reservados; se quedan mudos cuando se les habla en castellano. Pero en general me hago entender, cuando empiezan a llorar les digo algo en quechua entonces se calman. (Apud. VELAZCO; RÍOS, 2000, p. 16 e 17)

O relato das professoras indica uma oposição envolvendo língua materna e língua oficial que se apresenta como empecilho à efetividade da educação indígena, desde os primeiros anos de escolaridade até à inclusão integral de estudantes indígenas ao ingressarem em universidades. Na obra de Miranda, a partir de pares dicotômicos, principalmente envolvendo a linguagem, surgem outros que se estendem a aspectos históricos, sociais e culturais, como demonstra este fragmento do poema "L I":

¿Por qué lo abraza?

¿Y por qué se hace abrazar?

¿Han hablado?

¿Qué han hablado? ¿Y em qué idioma?

Los presidentes no hablan lenguas nativas.

¿Qué sobrevendrá a este acontecimiento?

¿Habrán acordado algo? ¿Se habrán reconciliado?

¿Habrán pactado? 
(MIRANDA, 2008, p. 61)

Motivado pela visualização de uma fotografia em uma página de jornal - "en la página central-, um presidente abraza a um indígena." - o sujeito poético conjectura o que poderia ter se passado naquele encontro. Alguns recursos estéticos, como a mistura de fontes em itálico ${ }^{5}$ e em letras normais, indicam a polifonia de vozes que questionam a fotografia do presidente abraçado a um indígena. As perguntas que surgem ao longo do poema, portanto, não representam dúvidas apenas do sujeito poético. Entre vários questionamentos, destaca-se a inviabilidade de um possível diálogo entre governantes e povos indígenas, pois aqueles não falam línguas nativas. Na última estrofe, como se apresentasse uma conclusão às indagações apresentadas nos versos anteriores, contrapõe-se a imposição da cultura do emigrante, simbolizada pela figura do presidente, à cultura da resistência aborígene, de que o indígena é o representante. Como demonstram os versos a seguir, o uso de letras sem itálico permite atribuir esta fala apenas ao sujeito poético:

Enigmas relampagueantes cruzan. Hasta esta fecha es el retrato de dos cumbres: la del poder de la cultura emigrada ¡y la de la resistência cultural aborigen! (MIRANDA, 2008, p. 61)

A linguagem pode ser considerada um dos elementos mais importantes no processo de colonização de povos nativos da América. O poema "M F" reflete sobre a expansão do domínio linguístico, como se observa na primeira estrofe:

La gramática española cuelga desde Europa sobre mis Andes, interceptando su sincretismo idiomático.

Sus grafias y fonemas, atacan con los caballos y las espadas de Pizarro.

Mi linguaje resiste, se refugia, lo persiguen, lo desmembran.

(MIRANDA, 2008, p. 68)

O sujeito poético, ainda no início do poema, sugere a resistência dos andinos em aprender a língua espanhola, porém, na estrofe seguinte, constata que "En tantos siglos

\footnotetext{
${ }^{5}$ Como esse recurso se repete ao longo da obra de Miranda, somente os versos grafados em itálicos pelo próprio autor manterão esse traço nos poemas citados neste trabalho.
} 
de guerra intercultural/ todas las batallas hemos perdido". Apesar desse histórico favorável aos "soldados intelectuales [... que] tienen todos los elementos a su alcance", ao longo do poema enfatizam-se tentativas para preservar línguas nativas, possivelmente o quéchua, à medida que o idioma do colonizador se espalha sobre os Andes. Os versos finais, contudo, ilustram o conflito de um sujeito que se sente mutilado à medida que entra em contato com um idioma alheio por meio da leitura de Miguel de Cervantes:

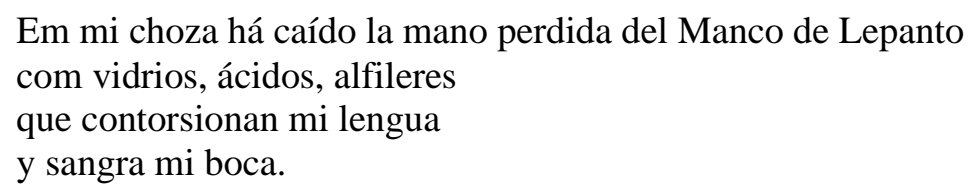
(MIRANDA, 2008, p. 68)

Voltando à análise do poema "E Q", além de ser citado em estudos voltados à reflexão sobre políticas educacionais, aparece, também, em discussões literárias relevantes, como em "Efraín Miranda: poética de lo telúrico", de Mauro Mamani Macedo. A análise desse poema sugere robjeções de professores enviados para lecionar no campo em se desvencilhar de suas culturas, bem como, de acolher a sabedoria dos indígenas, conforme este fragmento: “Lo campo se señala como un espacio no deseado, lugar donde a ningún maestro le gustaría ir a trabajar, y los que llegan allí imparten la educación con métodos, técnicas y conceptos que han sido configurados para otras realidades." (MACEDO, 2009, p. 96). Reconhecendo a relevância de tais estudos, este trabalho propõe uma análise comparativa dos poemas "E Q" e "Ñ R", buscando enfatizar a tensão entre opostos que permite observar tanto a visão da "indiecita escolar" quanto de mestres enviados para lecionar em territórios indígenas.

A linguagem tensional constitui uma das características fulcrais da poética de Miranda, principalmente no livro Choza (1978), de acordo com Relucé:

La escritura poética gusta de las polarizaciones de los sentidos, lo que explica la constante presencia de núcleos oposicionales que permiten que el efecto poético sea sorpresivo. El poema será entonces, la realización tensional de dos opuestos, de dos adversos. Los versos y las palabras de los versos asumen uma construcción tensional que se observa em las oposiciones que evidencian dos formas culturales contrapuestas. (RELUCÉ, 2008, p. 23). 
Ao apontá-la em poemas de diferentes livros, como proposto neste trabalho, pode-se pensar que a construção de sentido a partir da polarização de ideias e de palavras não se restringe ao poema ou a um livro isolado, mas se estende ao conjunto da obra, possibilitando o diálogo, mesmo que seja a partir de perspectivas dicotômicas, entre textos escritos em épocas distintas. A oposição de elementos que integram um mesmo processo, nesse caso o aluno, no poema "E Q", e o professor, em "Ñ R", pode ser observada nas razões que motivam insatisfações tanto na indiecita escolar quanto em seus Maestros. A quinta estrofe de "E Q" sintetiza a visão da aluna sobre a educação indígena:

\author{
Lloro porque soy índia y tengo una nina blanca \\ que el Maestro há creado dentro de mí; \\ esta nina no me puede; \\ el Maestro le da fuerzas y sustento \\ el Maestro tiene grandes métodos para esa nina. \\ El maestro se olvida de mí, de todos los alunos \\ y disse que para los índios no se há inventado nada. \\ (MIRANDA, 2008, p.93)
}

Aqui, o sujeito poético é uma menina indígena que, após se apresentar como "una indiecita escolar" conhecida do leitor - "mi retrato está em fólios de grandes libros; retratada com polleras y com uniformes" - indica o conflito com o qual precisa lidar. Ela se aflige com o fato de ser educada em um sistema que busca apagar sua identidade à medida que lhe impõem hábitos e costumes de outros povos. $\mathrm{O}$ choro da menina é motivado pelo choque cultural gerado por um modelo de ensino que desconsidera a sabedoria indígena e, por isso, cria um ser ambíguo, dividido entre suas origens e os conteúdos transmitidos na escola por um professor que desconsidera a importância do contexto a que seu aluno pertence, como indicam os versos finais:

\footnotetext{
A ratos me confude: me convierte en ella o ella em mí; cuando me habla el profesor, desaparece; en cada diciembre muere y cada abril resucita. Al concluir mis estudios se extinguirá en la parcialidade.
}

(MIRANDA, 2008, p.93)

No poema de Miranda, a indiazinha ganha voz para mostrar ao leitor, provavelmente "não-índio", outra faceta da educação indígena que publicações em livros, dados estatísticos e demais informações oficiais se encarregam de omitir. $\mathrm{O}$ 
sujeito poético que se expressa na primeira pessoa do discurso aponta algo que conhece na prática, portanto, está autorizado a questionar a eficácia de tais práticas de ensino para o seu desenvolvimento e demais membros da tribo. Portanto, suas palavras criticam o processo de branqueamento acirrado por modelos educacionais ofertados aos povos indígenas, no Peru e na América Latina.

Continuando a discussão a esse respeito, torna-se importante observar, também, a visão do professor que se desloca da zona urbana para trabalhar em comunidades rurais, como ilusram os seguintes versos de "Ñ R":

Las profesoras viajan a sus escuelas

Y regresan en los autos de la tarde.

Lloran su tragedia:

¡tener que trabajar en el campo!

El viento aletea contra sus rostros de terciopelo

Y el frío los quema, agrieta y encostra.

Lloran, una y otra vez, ante el espejo, ¡qué no harían por un traslado a la ciudad!

¡Educar indios, mirar indios, indios, indios, indios:

No comen ni duermen!

(MIRANDA, 2008, p.105)

Agora, diferente do que aparece em "E Q", temos um sujeito poético em terceira pessoa que, certamente, encontra-se em condições diferentes da vivida pelas personagens retratadas. Assim, o aborrecimento de professores que se deslocam até o território indígena para lecionar não é retratado por eles mesmos, mas por alguém que toma conhecimento de suas experiências por meio da observação ou da escuta de seus relatos. Tal escolha pela terceira pessoa do discurso pode ser vista como um recurso poético que possibilita a Miranda negar ao elemento dominante o direito à voz e a oportunidade de contar a sua versão da história. Traço bastante recorrente em sua obra, como pode ser observado nos poemas "L I", “36", "E F" e em vários outros. Assim, o descontentamento do aluno e, também, do professor passa a ser mostrado apenas pela perspectiva do indígena, ou com uma abordagem favorável à sua versão dos fatos. Cabe a ele, portanto, contar as duas histórias, tanto a que se passa consigo, na condição de aprendiz, quanto aquela retratando as inquietações de seus mestres. Trata-se de uma espécie de revanche em que o indígena, comumente silenciado, recebe a oportunidade de desfazer visões estereotipadas divulgadas a seu respeito em livros e outros registros oficiais. Além disso, mais do que falar de si, ele pode, agora, falar do outro, inclusive de aspectos comezinhos. 
Outro aspecto curioso nesse poema, se comparado ao "E Q", relaciona-se às razões para as lágrimas das professoras. Se a indiecita escolar chora devido ao conflito cultural acirrado por um modelo de ensino questionável, as professoras o fazem motivadas pela dificuldade em se adaptar ao território indígena onde assumiram a função de assegurar a esses povos o acesso à educação. Por um lado, a menina aponta aspectos negativos com base em questões coletivas que interferirão na cultura, na língua e na identidade de seu povo. Por outro, as professoras veem o que se passa consigo como uma tragédia a partir de aspectos pessoais e, na maioria das vezes, apontados como fúteis. O gesto narcisista de se olhar no espelho, lamentando o ressecamento da pele de veludo, representa uma crítica à associação de pontos indesejados dessa atuação profissional apenas a elementos que afetam o bem-estar e a aparência física das trabalhadoras.

O sujeito poético de "Ñ R" não menciona queixas das professoras em relação ao sistema de ensino ofertado aos povos indígenas. Demonstram insatisfação quanto às condições de trabalho que interferem em suas próprias vidas. A metáfora do espelho "El viento aletea contra sus rostros de terciopelo/ [...] Lloran, una y otra vez, ante el espejo," - simboliza uma crítica ao egocentrismo, que levam-nas a pensar apenas em si em vez de analisar, ou melhor contestar, a viabilidade de políticas públicas das quais são agentes. Nesse caso, as razões para o choro das professoras e da indiazinha criam outra dicotomia em torno de ideais de coletividade, muito caros ao universo indígena, e de individualidade, relacionadas a ações e pensamentos do "não-índio". Dessa maneira, os sujeitos poéticos de "E Q" e de "Ñ R" - quer em tom de denúncia, como se manifesta a indiazinha, quer em tom irônico, como se apresentam os lamentos das professoras transformam-se em representantes de uma instância coletiva.

Assim como a análise comparativa desses poemas indica diferentes visões apresentadas pelo par mestre/aluno, a tensão entre opostos, envolvendo diversos segmentos da sociedade, pode ser observada ao longo da obra de Miranda. No poema "L A", do livro Vida (1980), por exemplo, contrapõe-se a medicina convencional praticada por médicos diplomados em hospitais e centros cirúrgicos - a tratamentos baseados em conhecimentos ancestrais dos povos indígenas, como pode ser observado nas estrofes a seguir:

¡Hasta outro día ductores, erinas, laboratorios; pásenla bien cirujanos, enfermeiros, anestesistas; 
mejores tempos a jeringas, termómetros, gasas!

En el inmueble-choza me tomaron uma radioscopia de roedor: ¡Colerina e hígado!

El curandero me emplasto barro em toda la región abdominal; Me fajo solemnemente; conversó con médicos de la antigüedad; me miró desde todos los tempos; regresó com su próprio cuerpo, enseguida de haber ocupado los de otros...

(MIRANDA, 2008, p.103)

Nesse duelo entre saberes de povos tradicionais e tratamentos à base de remédios e procedimentos invasivos, a segunda opção mostra-se mais eficaz, a ponto de motivar o sujeito poético a fugir do hospital e buscar a cura em territórios indígenas.

Em “67”, de Padre Sol (1998), o jogo entre ideias díspares envolve questões religiosas, ao contrapor a imagem da Santa Trindade, dos cristãos, ao deus Birakocha ${ }^{6}$, dos povos andinos. O primeiro ponto de divergência entre as duas religiões relaciona-se a maneira como lidam com o trabalho. De acordo com o sujeito poético, em igrejas cristãs recomenda-se que

- “iGuarden esos trabajos. Ustedes están en la Iglesia.

Deben respetar la casa del Señor.

Aquí se viene a pedir perdón por los pecados

y a rogar al Señor por más pan!"

(MIRANDA, 2008, p. 77)

O poema se constrói a partir da intercalação de duas vozes. Uma, que aparece nos primeiros quatro versos, é marcada pelo uso de aspas a fim de indicar orientações feitas pelas catequistas. Nas dez estrofes seguintes, prevalecerá o discurso do sujeito poético apresentando seu ponto de vista acerca das duas religiões a partir de argumentos favoráveis àquela de matriz indígena. Uma das principais críticas relaciona-se ao desinteresse religioso por questões ligadas ao progresso e à ciência. Em determinada passagem, destaca-se a seguinte indagação: “ ¿Por qué las religiones no exaltan con símbolos propios/ el carácter maravilloso y transformador del trabajo?” (MIRANDA, 2008, p. 77). Questionamento que parece ser respondido pelas estrofes seguintes:

\footnotetext{
${ }^{6}$ De acordo com nota do organizador: "En pocas oportunidades Efraín Miranda hace uso de la lengua quechua. Escribe de acuerdo a su interpretación fonética, Birakocha y no Wirakocha ni Huiracocha." (RELUCÉ, Apud MIRANDA, 2008, p. 77).
} 
Nuestro dios Birakocha - preso y trabajandooye con apasionado interés la polifonía de los complejos sonoros:

talleres artesanales, factorías, aparatos automatizados, carriles de ensamblaje, hornos siderúrgicos dedos acionando em mesas de producción em serie...

Dios Birakocha, único de matéria inmersa em la energía, único de energia inmersa em la materia.

Dios Birakocha, único de la actividad cósmica y del trabajo ante los seres superiores.

(MIRANDA, 2008, p. 77 e 78)

De modo irônico, o sujeito poético insinua certa preguiça de outros deuses à medida que eles escolhem circunstâncias, rituais e lugares apropriados para agir, enquanto Birakocha nunca tira férias. Pelo contrário, a divindade indígena incorpora diferentes profissões, sendo, portanto, vinculada à ação transformadora, em vez de cultivar a fé passiva à espera por milagres.

No puedes autorizarte unas vacaciones.

A tan extraña ocurrencia - los habitantes todos del Planetaamaneceríamos sin la voluntad ni la iniciativa exigidas por el laboreo; dedicándonos em casas, templos, plazas, calles al enflaquecimiento, meditación y oración a otros dioses. (MIRANDA, 2008, p. 77 e 78)

Entre várias dicotomias que surgem ao longo da obra de Miranda, destaca-se uma em torno das imagens da "Madre Tierra" e do "Padre Sol", no poema "V Y". A partir do par Céu e Terra, sugere-se a conciliação de elementos contrários, propondo a unificação entre o que está acima e o que está abaixo como uma espécie de chamado à coletividade, conforme indicam os versos a seguir:

Levantamos horizontalmente los brazos:

cielo y tierra nos dan los suyos, unificamos los universos de arriba con los de abajo; no estamos solos, obramos en la plural unidad; actos materiales coordenamos con la materia rodeante, crezcan o decrezcan quedan y quedamos materia.

Los ejes con nuestra MadreTierra Fueron posesionados por el PadreSol, él, los heredó de su galaxia los mismos que le fueron asignados 
por sus consanguíneas extragalácticas.

(MIRANDA, 2008, p. 53 e 54).

Aqui a tensão entre opostos encaminha para a diluição de conflitos entre pares. Nesse movimento conciliatório, aos dois elementos - Céu e Terra - é acrescido um terceiro que sugere a integração entre cosmos e homem. Assim, a bipartição que se apresenta em "V Y" indica que o encontro de duas pontas contrárias, em vez de instaurar a diferença, pode criar consenso entre partes que integram o todo. Ao discorrer sobre a dicotomia como importante exercício de poder e dissimulação no contexto moderno, Bauman Zygmunt (1999, p.22) defende que, apesar de tal conceito ser produzido a partir da separação lado a lado, ele cria uma ilusão de conformidade e de que há um centro, um eixo ou uma linha divisória. Portanto, essa "falsa simetria dos resultados encobre a assimetria de poder que é a sua causa”. Embora sugira a igualdade e a troca de lugar entre as partes, a própria existência de ideias dicotômicas indica que há diferenças entre elas.

O jogo com díspares representa um dos traços que levam Miranda a ser considerado um poeta moderno, apesar de sua produção literária mais significativa ter sido publicada após a década de 1970, quando o Modernismo já soava como ultrapassado para boa parte dos poetas. Macedo (2009), ao relaciona o pós-modernismo ao distanciamento da literatura de assuntos vinculados à realidade imediata, salienta como o discurso de Miranda se afasta de uma visão centrista, definida pela metrópole e por outros estratos dominantes, enquanto apresenta sua obra a partir da ótica de povos marginalizados dos Andes. Em um contexto no qual o conhecimento não resulta do jogo dialético entre o objeto e o sujeito, a ênfase no "fazer-falar", ou seja, no virtuosismo da textualidade pura, levam alguns a subestimarem o conteúdo a ser transmitido. Para Macedo, à medida que não lida com o texto como se fosse mera criação poética estanque do real, Miranda segue um caminho inverso ao adotado por alguns contemporâneos seus. O fato de se voltar à realidade imediata, enquanto se isolou em comunidades indígenas para atuar como professor, relaciona-se ao distanciamento de Miranda da perspectiva pós-moderna, de acordo com Macedo:

Ante esta evación de la realidade, ante este despretigio de lo real, hay algunos que permanecieron como topos metidos em la tierra, hablando entre sus impares, transubstanciándose, fermentando su palavra, para luego ofrecerla como maduros frutos a la comunidad. Este ofertório de palabra que venía desde muy hondo, a veces se veía perturbado por el bosque de palavras artificiales que venía de afuera. Uno de esos topos 
es Efraín Miranda que, internado en el mundo andino, miraba con incredulidad este despliegue discursivo. (MACEDO, 2009, p. 91).

As mudanças culturais, artísticas e sociais observadas a partir de 1970 têm sido apontadas e analisadas por escritores e filósofos como pós-modernidade. Entre os estudos a esse respeito destacam-se O pós-moderno (1988), do francês Jean-François Lyotard, e Condição pós-moderna (2012), do norte-americano David Harvey. Embora abordem assuntos afins, esses autores apresentam opiniões diferentes acerca da pósmodernidade. Harvey (2012) discorre sobre tais mudanças culturais aproximando-as do contexto social e histórico em que se encontram. Aproximando-se de ideais marxistas, o autor não as isola de outras transformações pelas quais o mundo vem passando desde a transição do fordismo para a acumulação flexível, que ocasiona a compressão do tempoespaço. Lyotard (1988) alude às modificações ocorridas no âmbito do saber a partir de meados de 1970, idade pós-industrial, associando-as ao advento de novas tecnologias e da informatização.

Ao analisar essas mudanças sem se ater a contextos históricos ou sociais, assim como se observa nas abordagens de Harvey, Lyotard descreve o saber pós-moderno como o fim das metanarrativas, dos grandes relatos e do consenso universal. Baseado nas micronarrativas, o saber pós-moderno caracteriza-se pelo melhor desempenho (input/output) e pela deslegitimação do saber. Nesse contexto, desparece a noção de consenso, bem como delimitação entre o justo ou injusto, falso ou verdadeiro entre outros pares. Segundo Lyotard, no saber pós-moderno, o consenso passa a ser substituído pela paralogia que surge a partir da combinação dos jogos de linguagem defendidos por Ludwig Wittgenstein. Ao comparar a Linguagem humana a uma cidade, Wittgenstein afirma que

Não te deixes perturbar pelo facto de as linguagens consistirem apenas em ordens. Se queres dizer que, por esse motivo, não são completas, então pergunta-te se a nossa linguagem é completa; Se o era antes de a notação da Química e de a notação do cálculo infinitesimal terem sido nela incorporados, uma vez que estes são por assim dizer subúrbios da nossa Linguagem. (E com quantas casas e ruas é que uma cidade começa a ser cidade)? A nossa linguagem pode ser vista como uma cidade antiga: um labirinto de travessas e largos, casas antigas e modernas e casas em reconstruções de diversas épocas; tudo isto rodeado de uma multiplicidade de novos bairros periféricos com ruas regulares e as casas todas uniformizadas. (WITTGENSTEIN,1995, p. 183). 
De acordo com o autor, assim como não é possível definir quantas casas são necessárias para que uma cidade seja considerada como tal, a nossa linguagem se constitui a partir do entrelaçamento de fios de outras linguagens, numa espécie de jogo que leva à multiplicidade de combinações. Partindo dessa ideia, Lyotard descreve o saber pós-moderno como algo que se constrói com base em jogos de linguagem, tornando evidentes incomensurabilidades e singularidades. Como se trata da melhor performance - em que não há mais necessidade de descobrir, de revolucionar e de atestar a veracidade ou a justiça -, nesse "jogo de informações completas", cabe ao jogador combinar os "lances" de diversas maneiras. Por meio das combinações possíveis surgem a fragmentação e a pulverização de ideias. Ao fragmentar-se o saber nessa multiplicidade de jogos, perde-se a noção de problemas essenciais à medida que se a ênfase no individual leva ao desparecimento de instâncias coletivas. A esses saberes pulverizados se relaciona a paralogia, que consiste em colocá-los lado a lado, diluindo quaisquer traços em comum. Com sua inclinação para a heterogeneidade, a paralogia opõe-se à hegemonia do saber viabilizada pelo consenso. Desse modo, para Lyotard, no saber pós-moderno, o consenso torna-se um valor duvidoso e obsoleto.

A respeito do "consenso como um valor suspeito e ultrapassado", Harvey (2012) questiona a inconsistência do pensamento formulado por Lyotard (1988). Entre as fragilidades das ideias defendidas pelo francês, Harvey destaca o fato de defender a substituição dos metarrelatos por um saber construído com base em jogos de linguagem e legitimado pelas paralogias, ao mesmo tempo em que sugere que a justiça (uma metanarrativa) não pode ser considerada um valor ultrapassado. Para Lyotard, tanto o critério de operatividade quanto o consenso não são adequados para legitimar um vínculo social e definir o que é justo e verdadeiro, pois aquele é tecnológico, voltado mais à pragmática científica, enquanto este, por representar a uniformidade de opiniões, “violentaria a heterogeneidade dos jogos de linguagem". Nessa pragmática social em que a ideia de justiça não se relaciona nem ao consenso nem à performance, ele sugere que

[...] a invenção se faz no dissentimento. O saber pós-moderno não é somente o instrumento de poderes. Ele aguça nossa sensibilidade para as diferenças e reforça nossa capacidade de suportar $o$ incomensurável. Ele mesmo não encontra sua razão na homologia dos experts, mas na paralogia dos inventores. (LYOTARD, 1988, p. XVII)

Ao questionar se há PÓS-modernISMO ou pós-MODERNismo, ou seja, se a situação cultural, social e política que se observa a partir de 1970 pode ser considerada 
uma ruptura com o modernismo ou sua continuidade, David Harvey (2012) indica ser mais interessante vê-lo como uma aceleração, em vez de uma diferença. A pósmodernidade representa, portanto, uma crise do modernismo, por meio da qual se enfatiza seu aspecto fragmentário, efêmero e caótico, acrescentando-se, ainda, um profundo ceticismo diante do eterno e do imutável. Diante disso, Harvey chama a atenção para possíveis riscos representados pelo pós-modernismo, dos quais se destaca a preferência pela estética, em vez da ética. Isso eliminaria a possibilidade de uma política coerente e propiciaria aos que buscam atender a interesses escusos, inclusive do mercado financeiro, meios de se tornarem adeptos do neoconservadorismo reacionário. A respeito da ênfase à estética, Harvey corrobora as críticas feitas por Terry Eagleton a Lyotard, acusando-lhe de valorizar excessivamente a sedução retórica, equiparando-a à verdade e à autoridade. A importância atribuída à habilidade de argumentação, sugeridas pelos modos de combinar os "lances" nos jogos de linguagem, leva Harvey a estabelecer aproximações entre o pós-modernismo e a estetização política.

Nessa lógica de Harvey, ao buscar a desconstrução e a deslegitimação de toda espécie de argumento, por meio da fragmentação de vozes, os adeptos do pósmodernismo afastam-se de uma metateoria que abarque processos político-econômicos e suas consequências na vida das pessoas. Acerca da pulverização de vozes, sugerida pelos jogos de linguagem e pela paralogia a que se refere Lyotard, Harvey comenta que

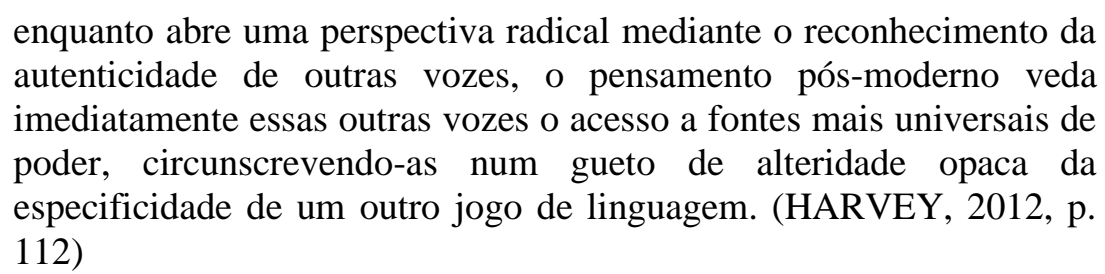

De acordo com ele, o maior risco da retórica pós-modernista relaciona-se à fragmentação das vozes, tornando os sujeitos menos propensos a enfrentar questões reais ligadas à economia política e ao poder global. Além disso, atenta para o fato de que, ainda que se busque negar as metanarrativas, em determinado momento, torna-se preciso recorrer a algum gesto ou conceito universalizante, como o fez Lyotard ao propor, de modo paradoxal, que o desejo de justiça se relacione ao "desconhecido" criado a partir da multiplicidade dos jogos de linguagem.

Com base nas análises apresentadas neste trabalho, é possível afirmar que a presença de pares antagônicos na poesia de Miranda, como a aluna indígena e as 
professoras brancas e outras dicotomias que se desdobram ao longo da obra permitem contrapor o universo indígena ao do colonizador. Ao apresentar os dois lados da história, a partir de uma perspectiva favorável ao indígena, a poesia de Miranda aproxima-se de princípios modernos baseados em esquemas dicotômicos. Portanto, ao polarizar a linguagem e a temática, a poética desse peruano (alguien doblemente marginal), em vez de apenas apontar diferenças entre opostos, propõe-se a rever de modo crítico processos que elegem certas culturas como dominantes enquanto buscam fragmentar e diluir as demais, silenciando suas vozes.

\section{Referências}

BAUMAN, Zygmun. Modernidade e ambivalência. Trad.: Marcus Penchel. Rio de Janeiro: Jorge Zahar. Ed., 1999.

HARVEY, David. Condição pós-moderna. Trad. Adail Ubirajara Sobral e Maria Stela Gonçalves. 23 ed. São Paulo: Edições Loyola, 2012.

KUDÓ, Inés. "La educación indigena en el Perú. Cuando la oportunidad habla una sola lengua". In: Etnicidad, Raza, Género y Educación en America Latina. PREAL. Octubre de 2004. p. 93-132. Disponível em:

http://thedialogue.org/PublicationFiles/EtnicidadRazayGenero.pdf

LYOTARD, Jean-François. O pós-moderno. Trad. Ricardo Corrêa Barbosa. 3 ed. Rio de Janeiro: José Olympio, 1988.

LLANO, Aymará de. "El estar y el ser en Efraín Miranda". In: Escritura y Pensamiento. Año XI, N. 23, 2008, p. 101-113. Disponível em:

http://revistasinvestigacion.unmsm.edu.pe/index.php/letras/article/view/7957

LÓPEZ, Luis Enrique. "La cuestión de la interculturalidad y la educación latinoamericana".In: Séptima Reunión del Comité Regional Intergubernamental del Proyecto Principal de Educación en América Latina y el Caribe. Año 2001. Disponível em: http://dcsh.xoc.uam.mx/sociales/Documentos/La_cuestion_de_la_interculturalidad.PDF

MACEDO, Mauro Mamani. Poéticas andinas. Puno. Lima: Pájaro de Fuego Ediciones; Guaraguao; Instituto de Investigaciones Humanísticas, 2009.

MIRANDA, Efraín. Indios dios runa: Antología poética del profeta del fuego. Estudio, selección y notas de Gonzalo Espino Relucé. Lima: Andesbooks, 2008.

MONTE, Nietta Lindenberg. "E agora, cara pálida? Educação e povos indígenas, 500 anos depois." Revista Brasileira de Educação. No 15. set/out/nov/dez. 2000.

Disponível em: http://www.scielo.br/pdf/rbedu/n15/n15a08 
RELUCÉ, Gonzalo Espino. "La aldea letrada quechua: la literatura quechua en el espacio de la literatura canónica del siglo XIX". In: Escritura y Pensamiento. Año IV, $\mathrm{N}^{\circ} .8,2001$, p. 101-114. Disponível em:

http://revistasinvestigacion.unmsm.edu.pe/index.php/letras/article/view/7559

RELUCÉ, Gonzalo Espino. “Literatura Inca (¿indígena?) como representación

de la literatura peruana”. In: Letras. Vol. 74. No 105/106. Lima: 2003, p. 109-125.

Disponível em: http://letras.unmsm.edu.pe/rl/index.php/le/issue/view/5

REYNOSO, Christian. "Efraín Miranda, en su ultima choza. In: LaRepublica.pe/Cultural. 12/04/2015. Disponível em http://punoculturaydesarrollo.blogspot.com/2015/04/efrain-miranda-in-memoriamcontinua.html Acesso em 15/06/2020.

VELAZCO, Graciela Soldevilla e RÍOS, Delma Gonzales. "Exclusion social y cultural: La educación en plobaciones indígenas como reto para la intervención professional", da Universidad Nacional del Altiplano. Puno-Perú. Disponível em: $\underline{\text { www.ts.ucr.ac.cr }}$

WITTGENSTEIN, Ludwig. Tratado lógico-filosófico/ Investigações filosóficas. Trad. e prefácio de M. S. Lourenço. 2. ed. Lisboa: Fundação Calouste Gulbenkian, 1995. 